\section{A VNTR isolated by size selection of human DNA fragments detects RFLPs at the extremity of $1 p$ and $4 q$}

\author{
D.Mariat, V.Lauthier and G.Vergnaud \\ Laboratoire de Génétique Moléculaire, Centre d'Etudes \\ du Bouchet, BP no. 3 91710, Vert le Petit, France
}

Source/Description: Human genomic DNA fragments above 1.5 $\mathrm{kb}$ after an Sau3A total digestion were used to construct a library (using a Puc 18 vector and a TG1 bacterial strain). Fifty clones were isolated, grown and plasmid minipreparations (1) were digested with HaeIII and HinfI.

The largest DNA insert called CEB8 was $3 \mathrm{~kb}$ in size after digestion with both enyzmes. It was used as a probe (2) on the panel of CEPH families.

At a high stringency CEB8 detects two loci which can be discriminated on the basis of band intensities (Fig. 1) (at a lower stringency many polymorphic bands are observed).

Polymorphism: CEB8 used on HaeIII digestions identifies two polymorphic loci, distinguishable by their relative intensities (Fig. 1).

D4F35S1 (strong signal): 17 alleles ranging $<1 \mathrm{~kb}$ to $10 \mathrm{~kb}$. $\begin{array}{llllllllllllllllll}\text { Size (kb) } \quad<1 & 1 & 1.5 & 2 & 2.5 & 3 & 3.5 & 4 & 4.5 & 5 & 5.5 & 6 & 6.5 & 7 & 8 & 9 & 10\end{array}$ $\begin{array}{llllllllllllllllll}\text { Frequency (\%) } & 21 & 1 & 0.5 & 6 & 21 & 13 & 10 & 10 & 4 & 7.5 & 1 & 2 & 0.5 & 0.5 & 1 & 0.5 & 0.5\end{array}$ D1F35S2 (weaker signal): 11 alleles ranging $<1 \mathrm{~kb}$ to $8 \mathrm{~kb}$.

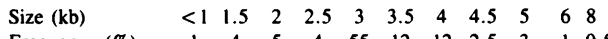

Frequency: D4F35S1: The heterozygosity rate in 120 unrelated individuals (grandparents, or parents when no grandparent is available) from the CEPH panel is 70\%. D1F35S2: 118 unrelated individuals and $78 \%$. (This is an underestimation since individuals with a small non-visible allele will be classified as homozygotes.) Chromosomal Localisation: The two loci have been localised by linkage analysis using the CEPH pedigree panel and CEPH database version 3 .

D4F35S1: to the extremity of the long arm of chromosome 4 (7 cM from L518, Lodscore 40).

D1F35S2: to the extremity of the short arm of chromosome 1 (3 cM from CMM121, Lodscore 43).

Mendelian Inheritance: Co-dominant segregation of the HaeIII RFLPs was observed in 40 families from the CEPH panel.

Other Comments: The probe is labelled by random priming, hybridised at $65^{\circ} \mathrm{C}$ overnight in a buffer containing $2 \%$ SDS; $0.45 \mathrm{M} \mathrm{Na}_{2} \mathrm{HPO}_{4} \mathrm{pH} 7.2 ; 1 \mathrm{mM}$ EDTA; $0.5 \%$ dried milk and washed at $70^{\circ} \mathrm{C}$ in $0.1 \mathrm{SSC}$ for $2 \times 45 \mathrm{~min}$.

References: 1) Zhou,C., Yang,Y. and Jong,A.Y. (1990) Biotechniques 8, 172-173. 2) Gannon,F. and Powell,R. (1990) Trends Genet. 6, 173.

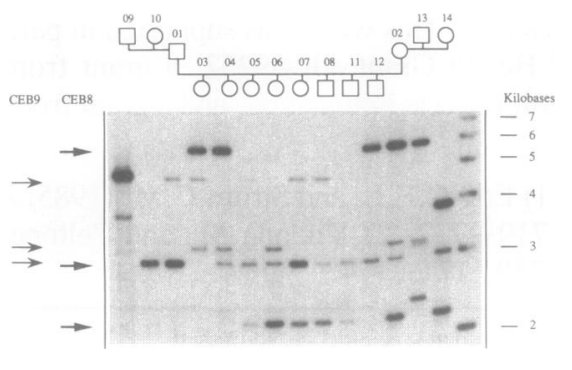

Mononucleotide repeat polymorphism in the APP gene

R.Mant, E.Parfitt, J.Hardy ${ }^{1}$ and M.Owen *

Departments of Psychological Medicine and Medical

Genetics, University of Wales College of Medicine, Heath

Park, Cardiff CF4 4XN and ${ }^{1}$ Department of Biochemistry

and Molecular Genetics, St Mary's Hospital Medical

School, London W2 1PG, UK

Source/Description: The polymorphic $(\mathrm{A})_{\mathrm{n}}$ repeat resides within intron 13 of the Amyloid Precursor Protein gene (APP) on human chromosome 21 . The polymorphism can be typed following amplification with PCR as described previously (1). The predicted length of the amplified sequence was $171 \mathrm{bp}$.

Primer Sequences:

GGAGTCTCTTGCATTACAAC (A strand)

TGTTGTTTAAAACCTCATTAAC (T strand)

Frequency: Estimated from 56 chromosomes of unrelated individuals.

$\begin{array}{ll}\text { Allele (bp) } & \text { Frequency } \\ \text { M1 } 173 & 0.02 \\ \text { M2 } 172 & 0.39 \\ \text { M3 } 171 & 0.34 \\ \text { M4 } 170 & 0.04 \\ \text { M5 } 168 & 0.05 \\ \text { M6 } 167 & 0.13 \\ \text { M7 165 } & 0.04\end{array}$

Mendelian Inheritance: Co-dominant segregation was observed in three informative families.

Chromosomal Localization: APP has been assigned to chromosome 21q21.2. Localization of the reported amplimere to chromosome 21 was confirmed by amplification of DNA from a somatic cell hybrid WA17 that contains 3 copies of human chromosome 21 (2).

Other Comments: The PCR was performed on $20 \mathrm{ng}$ of genomic DNA using 50 pmoles of each oligonucleotide primer. Samples were processed through 27 cycles consisting of $20 \mathrm{~s}$ at $94^{\circ} \mathrm{C}, 20 \mathrm{~s}$ at $56^{\circ} \mathrm{C}$ and $30 \mathrm{~s}$ at $72^{\circ} \mathrm{C}$. Reaction buffer contained $1.8 \mathrm{mM}$ $\mathrm{MgCl}_{2}, 10 \mathrm{mM}$ Tris- $\mathrm{HCl} \mathrm{pH} 9,50 \mathrm{mM} \mathrm{KCl}, 0.01 \%$ w/v gelatin, $0.1 \%$ Triton $\mathrm{X} 100$. Each allelic fragment appears on the autoradiograph as three prominent bands. The central (also darkest) band was used to define the allele size.

Acknowledgements: This work was supported by the Wellcome Trust and the MRC.

References: 1) Weber and May (1989) Am. J. Human Genet. 44, 388-396. 2) Raziuddin et al. (1984) Proc. Natl. Acad. Sci. USA 81, 5504-5508.

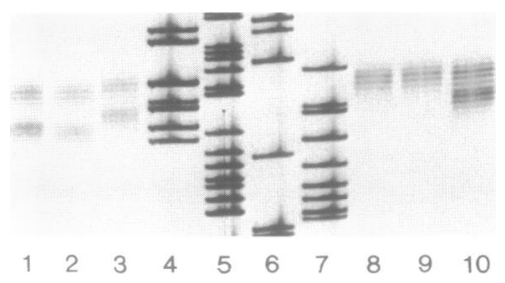

* To whom correspondence should be addressed 